\title{
Influence of preoperative supplementation of omega-3 fatty acid in the healing of colonic anastomoses in malnourished rats receiving paclitaxel
}

\author{
Influência da suplementação pré-operatória com ácido graxo ômega-3 na \\ cicatrização das anastomoses colônicas em ratos desnutridos que receberam \\ paclitaxel
}

Alvo Orlando Vizzotto Junior ${ }^{1}$; Antonio Carlos Ligocki Campos, TCBC-PR²; Eneri Vieira de Souza Leite Mello3; Tiago Jacometo CASTILHO, ACBC-PR 1

\section{A B S T R A C T}

\begin{abstract}
Objective: To evaluate the effect of preoperative supplementation of omega-3 fatty acids on the healing of colonic anastomoses in malnourished rats receiving paclitaxel. Methods: we studied 160 male Wistar rats, divided in two groups: one subjected to malnutrition by pair feeding (M) for four weeks, and another that received food ad libitum (W). In the fourth week, the groups were further divided into two subgroups that received omega-3 or olive oil by gavage. The animals were submitted to colonic transection and end-to-end anastomosis. After the operation, each of the four groups was divided into two subgroups that received intraperitoneal isovolumetric solutions of saline or paclitaxel. Results: mortality was $26.8 \%$ higher in the group of animals that received paclitaxel $(p=0.003)$. The complete rupture strength was greater in well-nourished-oil Paclitaxel group (WOP) compared with the the malnourished-oil Paclitaxel one (MOP). The collagen maturation index was higher in well-nourished-oil saline group (WOS) in relation to the malnutrition-oil-saline group (MOS), lower in malnourished-oil-saline group (MOS) in relation to malnourished-ômega3-saline one (M3S) and lower in the well-nourished-omega3-saline group (W3S) compared with the malnourished-omega3-saline (M3S). The blood vessel count was higher in the malnourished-oil-saline group (MOS) than in the malnourished-oil-paclitaxel group (MOP) and lower in the malnourished-oil-saline group (MOS) in relation to the malnourished-omega3-paclitaxel group (M3P). Conclusion: supplementation with omega-3 fatty acids was associated with a significant increase in the production of mature collagen in malnourished animals, with a reversal of the harmful effects caused by malnutrition associated with the use of paclitaxel on the rupture strength, and with a stimulus to neoangiogenesis in the group receiving paclitaxel.
\end{abstract}

Key words: Anastomosis, Surgical. Malnutrition. Omega-3 Fatty Acids. Paclitaxel.

\section{INTRODUCTION}

O varian cancer is the second most common gynecological cancer in Brazil, with an annual mortality of about 15,000 cases $^{1}$. It is often diagnosed at a stage when there is peritoneal dissemination, and has surgery as its initial treatment approach with the aim of ideal cytoreductive resection, i.e., residual disease that is less than $0.5 \mathrm{~cm}^{2}$. To this end, intestinal segments resection and performance of colonic anastomosis are frequently required. Early chemotherapy containing paclitaxel is an important treatment element ${ }^{3}$. The healing process of these colonic anastomosis takes place in an adverse environment, under the effects of malnutrition, which is very common in patients with ovarian cancer with peritoneal dissemination, and of the immunosuppressive effects of chemotherapy ${ }^{4}$.
Preoperative food intake is crucial to ensure that the postoperative healing process will properly occur ${ }^{4-6}$. Although preoperative adequate renutrition is difficult in such patients, supplementation with specific nutritional elements in small volumes can be an alternative to accomplish it, especially if the substrate has a nutritional modulatory role in the healing process, enabling it to elapse with smaller effects of malnutrition ${ }^{7}$.

Experimental studies conducted to evaluate the effect of paclitaxel in colonic anastomosis in rats showed that when administered in the postoperative period, this drug hampers the healing process ${ }^{8.9}$. In this scenario, the omega-3 fatty acids have been proposed as a nutritional element that allow caloric intake and favorable modulation of the inflammatory process and healing ${ }^{4,10,11}$.

This study evaluated the effect of preoperative supplementation of omega-3 fatty acids on the healing of

1. Oncology Service, Santa Rita Hospital, Maringá, Paraná State - PR, Brazil; 2. Department of Surgery, Universidade Federal do Paraná, Curitiba, PR; 3. Department of Morphological Sciences, UEM, Maringá - PR. 
colonic anastomoses in malnourished rats receiving intraperitoneal paclitaxel.

\section{METHODS}

Experimental design and administered solutions

We used 160 male Wistar rats (Rattus norvegicus albinos, Roentia Mammalia) with body weight ranging from 200 to 330 grams $(288.76 \pm 4,45 \mathrm{~g})$ from the vivarium of the State University of Maringá. The animals were housed in individual boxes and divided into two main groups: $\mathrm{W}$ well-nourished rats $(n=80)$ who received food and water ad libitum; $M$ - malnourished rats $(n=80)$ who received half the amount of the diet that their well-nourished pairs had received the previous day (malnutrition process, pair feeding method). Each group was divided into four subgroups with 20 animals each, according to lipid supplementation and the administration of saline or paclitaxel.

The lipid solutions were extra-virgin olive oil emulsion and omega-3 fatty acids consisting of eicosapentaenoic acid (EPA) and docosahexaenoic acid (DHA) in a ratio of $80: 20$ and concentration of $20 \mathrm{mg} / \mathrm{ml}$. The administration comprised a single daily dose of $100 \mathrm{mg}$ / kg via orogastric gavage without anesthesia.

The drug used was paclitaxel at a dose of 3.5 $\mathrm{mg} / \mathrm{kg}$ diluted in isotonic saline solution at a concentration of $0.35 \mathrm{mg} / \mathrm{ml}$. The administration of chemotherapy or $0.9 \%$ isotonic saline solution was carried out with intraperitoneal injection, immediately after the surgical procedure.

The well-nourished rats $(\mathrm{W})$ received chow ad libitum the four weeks prior to the procedure and were divided into four subgroups, being supplemented with: WOS - olive oil and saline; W3S - omega 3 and saline; WOP - olive oil and paclitaxel; and W3P - omega 3 and paclitaxel. The malnourished rats $(\mathrm{M})$ were divided into four subgroups and were supplemented with: MOS olive oil and saline; M3S - omega 3 and saline; MOP olive oil and paclitaxel; and M3P - omega-3 and paclitaxel.

\section{Surgical procedure and evolution}

The surgical procedure, conducted under general anesthesia with a combination of $10 \mathrm{mg} / \mathrm{kg}$ xylazine and $50 \mathrm{mg} / \mathrm{kg}$ ketamine, consisted of two colon transections (colostomies), one at the colon proximal segment, $4.0 \mathrm{~cm}$ from the ileocecal valve, and one at the distal colon segment, $3.0 \mathrm{~cm}$ above the peritoneal reflection of the rectum. The reconstructions were performed in total single plane end-to-end anastomosis with interrupted suture using eight stitches of 6-0 monofilament, synthetic, nonabsorbable suture (Ethicon?). After anesthetic recovery all animals received food and water ad libitum until the time of death.
We observed and weighed the animals daily, and those which died underwent necropsy to evaluate the presence of fistula or peritonitis. Euthanasia, with a lethal dose of ketamine and xylazine association, was taken on the fifth day after surgery. After death, the animals underwent celiotomy for evaluation of the following: presence of wound infection, adhesions (by the Knigthly index) ${ }^{12}$ and anastomotic complications (dehiscence or stenosis). Then we excised the proximal and distal colon segments containing the anastomoses. The proximal segments, about $2.0 \mathrm{~cm}$ long, were named proximal specimen (PS) and used for pathological and immunohistochemical study. The distal segments, $4 \mathrm{~cm}$ long, were named distal specimen (DS) and subjected to tensile test.

\section{Tension trial}

The distal specimen was subjected to tensile test, using a computerized mechanical testing machine (EMIC $($ ). Tension was applied with a $50 \mathrm{~mm} /$ minute speed. We used a $1 \mathrm{Kg}$ load cell with a sensitivity of 50 grams for a $4500 \mathrm{gf}$ strength limit, until complete anastomotic rupture. The variables evaluated were the maximum tensile strength (MTS) and the complete rupture strength (CRS), measured in Newtons (N), and the maximum tension (MT), measured in $\mathrm{N} / \mathrm{cm}^{2}$.

\section{Histological evaluation}

The proximal specimen was fixed in buffered $10 \%$ formalin and sent for histological processing and evaluation by hematoxylin-eosin (HE), picrosirius-red (PSR) and immunohistochemistry.

HE staining was used to assess the degree of inflammatory reaction (poly and monomorfonuclear infiltrate), interstitial edema, vascular congestion, granulation tissue and fibrosis. The data were classified as severe, moderate, mild or absent, and transformed into quantitative variables by assignment of indexes to the histological findings, as follows: absent, index 0; discrete, index 1; moderate, index 2; and severe, index 3.

The staining with F3BA picrosirius-red was made to identify the mature and immature collagen fibers by microscopy technique with polarized light and computerized morphometric analysis. Each section was assessed by optical microscopy at 200x magnification using a polarized light source (C-SP simple polarizer). We analyzed two fields, proximal and distal to the anastomotic line, containing the entire thickness of the colonic segment. The images were captured by a Nikon DS-FI1C camera and transmitted via the D-DA simple system analyzer, to the $\mathrm{G} 205 \mathrm{HV} \otimes$ color LCD monitor, frozen and scanned. We then performed image analysis using the Image Pro-plus ${ }^{\mathrm{TM}}$ software. In the RGB ("Red, Green, Blue") system, we quantified areas of mature collagen fibers - collagen type I (shades of red, yellow and orange) - and immature ones - type III collagen (green tones). We computed the between the area 
percentages of collagen type I and collagen type III, determined as collagen maturation index (CMI).

\section{Immunohistochemical evaluation}

By immunohistochemical method, we evaluated CD31 (Monoclonal, JC70 code, Cell Marque, Moleenstraat, $\mathrm{NL}$ ), calponin (Monoclonal, code CALP, Cell Marque, Moleenstraat, NL) and Ki-67 (Monoclonal, SP6 code, Cell Marque, Moleenstraat, NL), on separate slides. We used these markers to evaluate neoangiogenesis, research for myofibroblasts, and for cells in the replication phase (other than G0) present in the healing process area. We carried out antigen retrieval by exposing the materials to heat and pressure. Development of the slides was made by Diaminobenzidine (DAB) brown chromogen; the detection technique, by HRP-polymer (free biotin). We used positive and negative controls to validate the reactions. We examined the slides under 200x magnification to count vessels and $400 x$ to count myofibroblasts and proliferating cells. The images were made using the pictures OPT 5000 Power Opticam $®$ capture system, of 5.0 megapixels, connected to a computer with image analysis software (VMS 3.5 Measuring Software HPower®). We performed quantitative analysis of the number of vessels, fibroblasts and proliferating cells in the area of the anastomosis, as well as $10 \mathrm{~mm}$ proximal and $10 \mathrm{~mm}$ distal to it, in four randomly selected different fields.

\section{Statistical analysis}

We carried out the statistical analysis according to the nature of the data. We used parametric tests for quantitative variables with normal (Gaussian) distribution. For comparison between all groups, was applied the analysis of variance (ANOVA), and for the pair-wise comparison of groups, we used the Student's t test. For quantitative variables without normal (Gaussian) distribution, we used non-parametric analysis. For comparison between all groups, we applied the Kruskal-Wallis test, and for pair-wise analysis, the Mann-Whitney test (Wilcoxon test for independent groups). We evaluated dichotomous variables, such as a fatal outcome, presence of wound infection and anastomotic complications (dehiscence or stenosis) by the chi-square test and the Cochran test. The level of significance was $p<0.05$.

\section{RESULTS}

Of the initial 160 animals experiment on, 117 survived until the day of euthanasia, with an overall mortality rate of $26.8 \%$. Of the 43 deaths, 42 were for anastomotic complications, 15 in the animals receiving saline and 28 in groups receiving paclitaxel, significantly higher in the latter $(p=0.03)$.

The average weight of the animals was $294.8 \pm$ $1,67 \mathrm{~g}$. There was no difference between the groups average weight on the first day (D1) of the experiment ( $p=0.8037$ ). The animals of well-nourished groups had an average weight gain of $23.1 \%$ between D1 and D28. The animals of the malnourished groups had an average weight loss of $16.6 \%$ between D1 and D28. Between the day of the operation and the euthanasia there was a mean weight loss of $18 \%$ in the well-nourished group and $10 \%$ in the malnourished group (Figure 1).

On the operation day (Figure 2), the average weight of the MOS group $(236.5 \pm 4.2 \mathrm{~g})$ was significantly lower $(p<0.05)$ than the average M3S group weight $(253.8$ $\pm 4.1 \mathrm{~g})$.

Anastomotic stenosis occurred in 14 rats of the well-nourished group and in 31 of the malnourished group, being significantly higher in this group $(p=0.007)$.

Full tensile strength (Figure 3 ) was significantly higher in the WOP group compared with the MOP group $(1.28 \pm 0.17$ vs. $0.77 \pm 0.07, p<0.05)$. There was no difference between the groups in terms of maximum tension $(p=0.2119)$ and for the maximum tensile strength $(p=$ $0.3638)$

The mean intensity of the inflammatory infiltrate (Figure 4) was significantly lower in the MOS group compared with the M3S group $(1.61 \pm 0.78$ vs. $2.50 \pm$ $0.63, p<0.05)$.

Regarding the collagen maturation index (CMI) (Figure 5), it was significantly higher in the WOS group than in the MOS one $(1.45 \pm 0.4$ vs. $0.35 \pm 0.08, p<0.05)$, significantly lower in the W3S group than in M3S one (2.08 \pm 0.35 vs. $2.82 \pm 0.33, p<0.05)$, and significantly lower in the MOS group than in groups M3S $(0.35 \pm 0.08$ vs. $2.82 \pm$

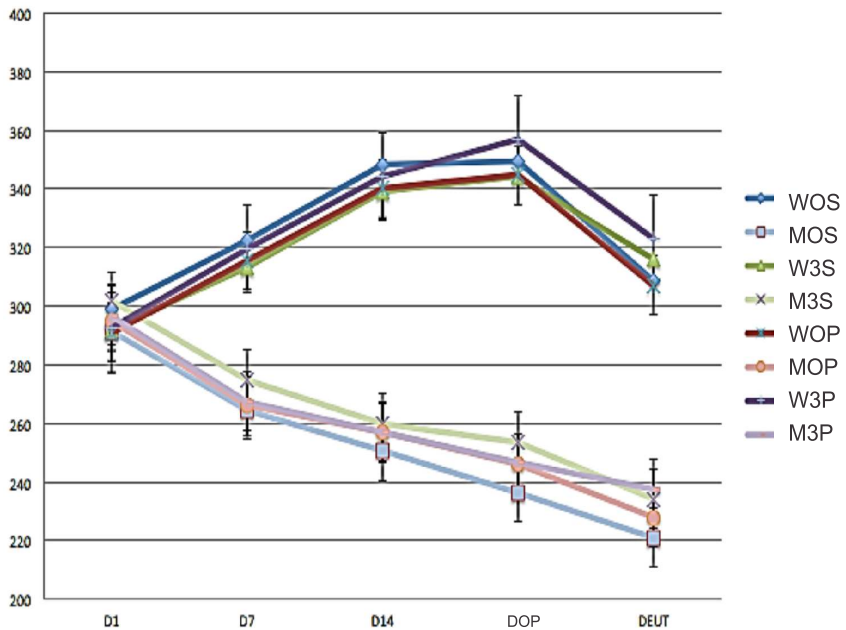

Figure 1 - Evolution of animal weight.

X-axis: days of the experiment - D1: Day 1; D7: $7^{\text {th }}$ day; D14: $14^{\text {th }}$ day; DOP- day of operation; and DEUT: day of mice death (euthanasia)

Y-axis: Weight (grams). WOS: well-nourished-oil-saline; W3S: wellnourished-omega-3-saline; WOP: well-nourished-oil-paclitaxel; W3P: well-nourished-omega-3-paclitaxel; MOS: malnourished-oil-saline; M3S: malnourished-omega-3-saline; MOP: malnourished-oil-paclitaxel; M3P: malnourished-omega-3-paclitaxel. 
$0.33, \mathrm{p}<0.05)$ and $\mathrm{MOP}(0.35 \pm 0.08$ vs. $1.58 \pm 0.15$ $\mathrm{p}<0.05)$.

The average blood vessels count (Figure 6) was significantly higher in the M3S group compared with the MOP group $(12.64 \pm 1.7$ vs. $6.45 \pm 0.28, p<0.05)$ and significantly lower in the MOP group in relation to the M3P group $(6.45 \pm 0.28$ vs. $8.91 \pm 0.88, p<0.05)$.

\section{DISCUSSION}

The overall incidence of deaths in this study was $26.5 \%$, consistent with other studies using similar methodologies. Trubian observed $24.5 \%$ of deaths when assessing malnutrition with toxemia induction ${ }^{13}$. The mortality rate was higher in the groups receiving paclitaxel compared with the groups that received saline, most due to anastomotic postoperative complications.

The immunosuppressive action of chemotherapy drugs such as paclitaxel is one of the possible factors associated with higher death rates observed in the groups receiving this drug ${ }^{2,14}$. Another possible explanation for this higher death rate is because such drugs act by inhibiting cell proliferation by different mechanisms of action. As such proliferation is essential in the healing process, they play an important attenuation of the fibroplasia process $8,9,15$. The inhibitory action on fibroplasia results in higher anastomotic dehiscence rate, causing fistula and fecal peritonitis ${ }^{15}$, which is consistent with what was observed at the animals' necropsy.

The average starting weight of the animals in all groups was homogeneous. The induction of protein-energy malnutrition, by restriction to $50 \%$ of the standard diet, promoted progressive weight loss during the 28 days. The animals in well-nourished groups had an average weight gain of $23.1 \%$ between D1 and D28, while the ones in malnourished group had a mean weight loss of $16.6 \%$ between D1 and D28. The average weight of the malnourished group was lower compared with the wellnourished ones at the end of 28 days, showing the efficiency of the food restriction procedure on obtaining malnutrition. Similar results were found in other studies ${ }^{13,16}$.

Relatively few studies have evaluated the role of supplementation of omega-3 fatty acids in postanastomosis recovery of the digestive tract, most of them clinical studies. Clinical trials such as the ones of Farreras et al., in 200517, Torrinhas, 20134, and Aoyama et al., in $2013^{18}$, evaluated the effect of omega-3 fatty acids supplementation in patients undergoing digestive tract anastomosis. Only in the latter, the weight was evaluated as a nutritional recovery indicator, and the omega-3 fatty acids had an important role for nutritional recovery and weight gain in postoperative patients undergoing gastroenteric anastomosis for stomach cancer ${ }^{18}$.

We also observed that in the operation day, after one week of olive oil or omega-3 fatty acids administration,

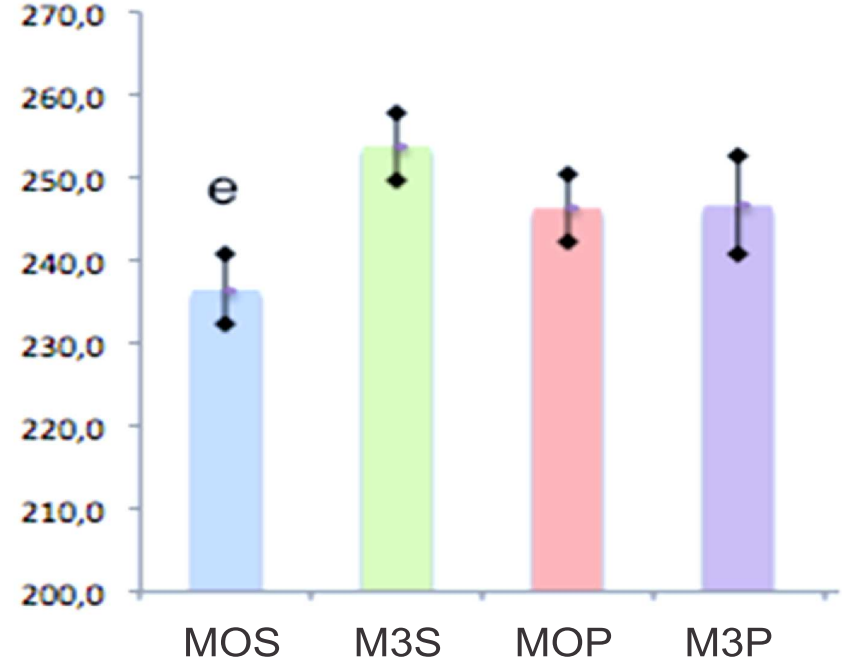

Figure 2 - Mean weights in malnourished groups on the day of operation. Y-axis: weight in grams; X-axis: groups: MOS - malnourished-oil-saline; M3S - malnourishedomega-3-saline; MOP - malnourished-oil-paclitaxel; M3P - malnourished-omega-3-paclitaxel; e - Average of MOS group weight is smaller than the average weight of M3S group ( $p<0.05)$.

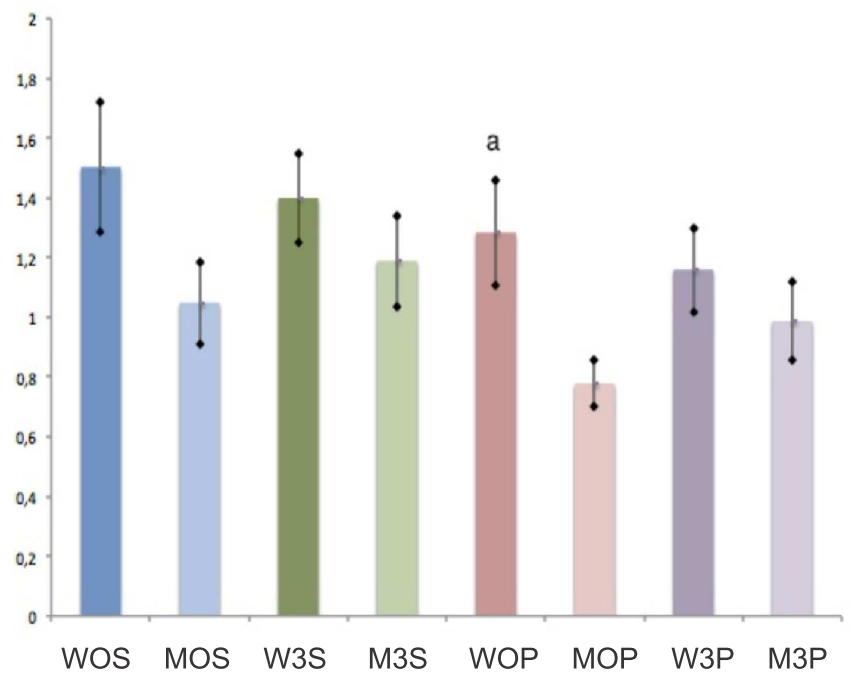

Figure 3- Complete Rupture Strength (CRS) in groups. Y-axis: force in Newtons. $X$ axis: groups; WOS: well-nourishedoil-saline; W3S: well-nourished-omega-3-saline; WOP. well-nourished-oil-paclitaxel; W3P: well-nourishedomega-3-paclitaxel; MOS: malnourished-oil-saline, M3S: malnourished-omega-3-saline; MOP. malnourished-oil-paclitaxel; M3P: malnourishedomega-3-paclitaxel. There was no significant difference between groups ( $p=0.3638$ ).

the MOS group mean weight was greater than the M3S group. This finding, consistent with the literature, suggests that supplementation with omega-3, besides favorably modulating the anastomotic healing process, also contributes as an important nutritional energy intake factor in the recovery from undernourishment ${ }^{18}$. 


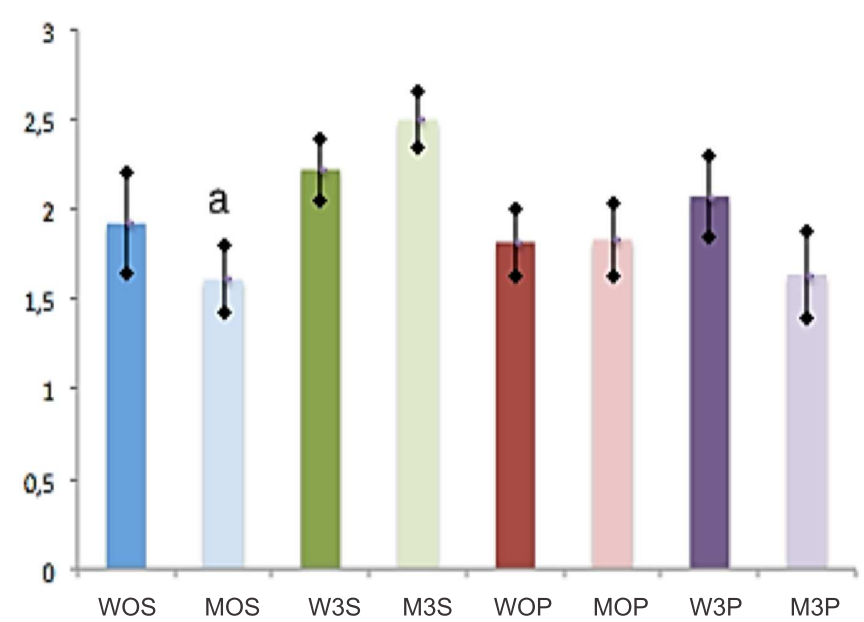

Figure 4 - Intensity of the inflammatory infiltrate at HE. $Y$-axis: intensity index of inflammatory infiltrate.

$X$ axis: groups. WOS: well-nourished-oil-saline; W3S: well-nourishedomega-3-saline; WOP: well-nourished-oil-paclitaxel; W3P: wellnourished-omega-3-paclitaxel; MOS: malnourished-oil-saline; M3S: malnourished-omega-3-saline; MOP: malnourished-oil-paclitaxel; M3P: malnourished-omega-3-paclitaxel.; a-intensity of the inflammatory infiltrate of the MOS group significantly lower than of the M3S group $(p<0.05)$.

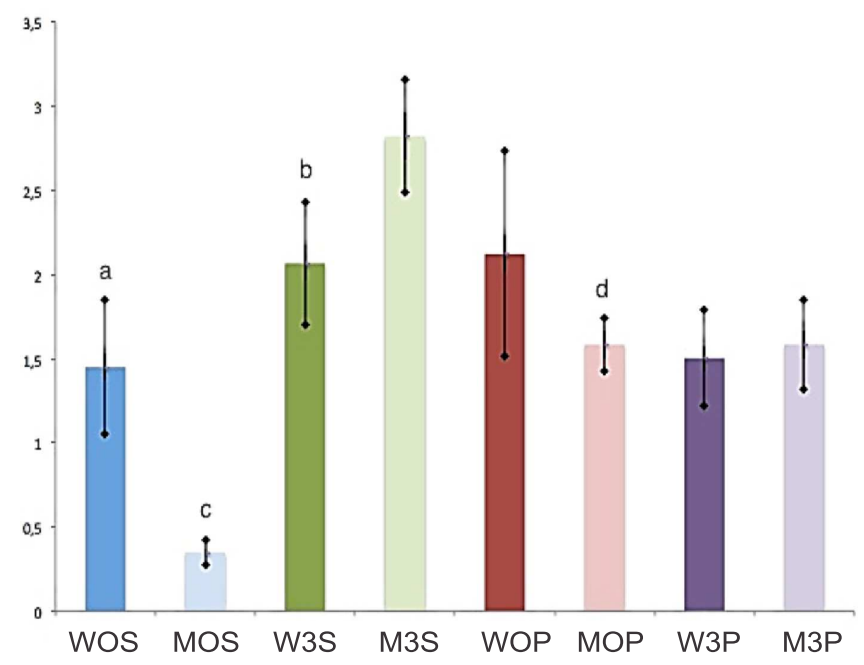

Figure 5 - Collagen maturation index.

$Y$-axis: collagen maturation index (CMI) average.

$X$ axis: groups. WOS: well-nourished-oil-saline; W3S: well-nourishedomega-3-saline; WOP: well-nourished-oil-paclitaxel; W3P: wellnourished-omega-3-paclitaxel; MOS: malnourished-oil-saline; M3S: malnourished-omega-3-saline; MOP: malnourished-oil-paclitaxel; M3P: malnourished-omega-3-paclitaxel;

a- WOS CMI was significantly higher than MOS $(p<0.05)$;

$b$ - W3S had significantly lower average CMI than M3S ( $p<0.05)$;

$c$ - MOS had significantly lower average CMI than M3S ( $p<0.05)$; and $d$ - MOS had significantly lower average of CMI that MOP $(p<0.05)$.

Of the three measured tensile resistance strengths, the maximum tensile strength (MTS) and the maximum tension (MT) did not differ between groups. Concerning the complete rupture strength (CRS), it was

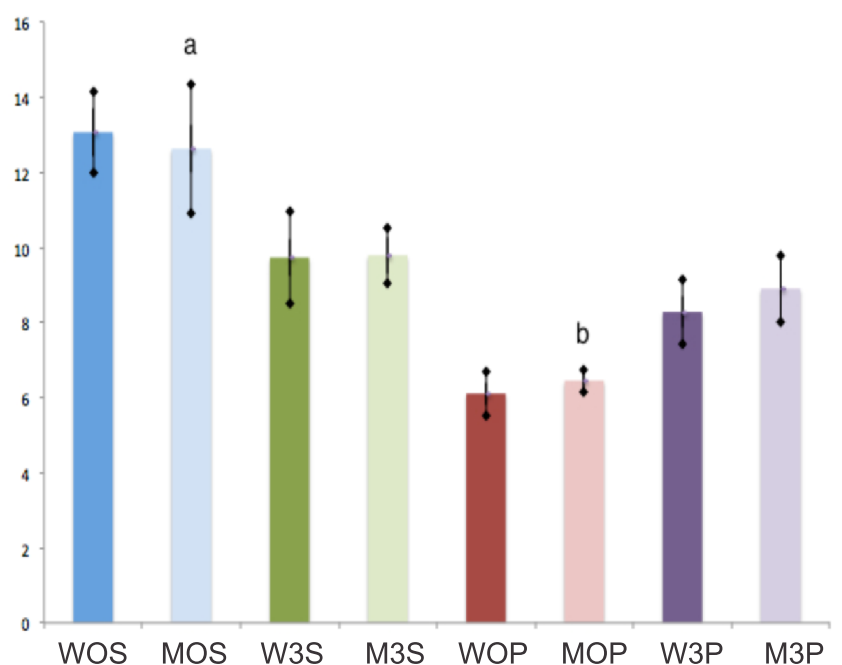

Figure 6 - Number of blood vessels according to the CD 31 marker.

$Y$-axis: number of vessels.

$X$ axis: groups. WOS: well-nourished-oil-saline; W3S: well-nourishedomega-3-saline; WOP: well-nourished-oil-paclitaxel; W3P: wellnourished-omega-3-paclitaxel; MOS: malnourished-oil-saline; M3S: malnourished-omega-3-saline; MOP: malnourished-oil-paclitaxel; M3P: malnourished-omega-3-paclitaxel;

a- number of vessels was significantly higher in MOS the group than in MOP $(p<0.05)$;

$b$ - number of vessels was significantly lower number in the MOP group than in $M 3 P(p<0.05)$.

lower in the MOP group when compared to the WOP. Malnutrition associated with paclitaxel played a deleterious role on the anastomotic tensile strength. In this sense, experimental studies that evaluated the effect of malnutrition ${ }^{13,16}$ and the use of chemotherapy ${ }^{15}$ on the on the rupture strength of colonic anastomoses in rats also observed its significant reduction due to harmful effects of such drugs on the healing process.

The induction of protein-energy malnutrition interferes systemically in protein synthesis. Possibly, this effect also occurs in the anastomotic site, hampering collagen synthesis. As the synthesis of collagen in the anastomosis is one of the major recovery factors of tensile resistance strength ${ }^{13,19}$, disturbances in this synthesis are possibly associated with a reduction in tensile strength. This mechanism might explain the finding of reduced complete rupture strength (CRS) in the MOP group in relation to the WOP one. The also lower collagen maturation index (ratio between mature and immature collagen) in the MOP group when compared with the WOP, although not significant, corroborates this idea.

The action of chemotherapy on cell proliferation attenuates the fibroplasia process $5^{8,9,15}$. Possibly this is an enhancer element of the malnutrition inhibitory effects on protein synthesis, especially collagen in the anastomotic site. These elements, malnutrition and paclitaxel administration, acting concurrently, probably explain the reduction of CRS in the MOP group in relation to the WOP 
group, as this reduction was not observed in the group of animals submitted only to malnutrition without paclitaxel administration (MOS) in relation to the WOS group.

On the other hand, there was no significant difference in CRP between the M3P and W3P groups. This finding suggests that nutritional supplementation with omega-3 fatty acids can reverse the deleterious effects caused by the association of malnutrition and paclitaxel administration in colonic anastomosis CRS, for the significant reduction of this force, observed in the MOP group in relation to the WOP one, was not observed when the M3P group was compared with the W3P group. This finding is consistent with the ones of Ekçi et al. ${ }^{20}$, who also observed a significant increase in the colonic anastomosis rupture pressure of rats receiving dietary supplementation with omega-3, although used in combination with ascorbic acid. The favorable modulation of omega-3 on collagen synthesis in the anastomotic site is one possible explanation for the observed recovery of the colonic anastomosis rupture strength.

We also noted an increase in cell activity in the anastomotic site, considered as inflammatory infiltrate, in the M3S group compared with the M3S one. This finding reinforces the idea that omega-3 has immunomodulating effects in inflammation and healing, by stimulating cellular activity, and corroborates the findings of McDaniel et al. ${ }^{21}$, who observed an inflammatory infiltrate increase of human healing skin wounds, as well as a significantly higher level of interleukin 1â (IL-1 â) in the inflammatory lesion fluid in the group that received the administration of EPA and DHA. This finding may seem conflicting with that proposed in the literature, that the omega-3 fatty acids have less pro-inflammatory activity by replacing arachidonic acid (omega- 6 fatty acid) in the cell membrane and increase, through its metabolism, the production of eicosanoids of lower inflammatory potential, such as leukotriene $B_{5}$ and prostaglandin $\mathrm{E}_{3}{ }^{10,22}$. Authors speculate that this increased cellular activity of the anastomotic environment is due to specific cell types, such as macrophages, fibroblasts, and myofibroblasts. It is possible that at the anastomotic site eicosanoids derived from the omega-3 fatty acids, although display an inhibitory effect on the inflammatory process in general, can stimulate the proliferation of specific cell types. The largest production of mature collagen (CMI) in the M3S group compared with the M3S one contributes indirectly to this idea, as this increased production is correlated with increased activity of cells producing collagen (fibroblasts and myofibroblasts) in the anastomotic environment.

The evaluation of collagen densitometry showed a significant reduction of mature collagen (type I) in relation to the immature one (type III), when assessed by the collagen maturation index (CMI), in the MOS group compared with the WOS group. This finding suggests that malnutrition is an important factor reducing the production of mature collagen in the healing anastomosis. Trubian also observed a reduction of $\mathrm{CMI}$ in groups of malnourished rats compared with the group of well-nourished ones ${ }^{13}$

The recovery of the tensile strength is more related to type I collagen than with type III one. The deposition and remodeling of type I collagen fibers is the main factor for recovery of anastomotic resistance ${ }^{19}$.

The M3S group showed an important gain of mature collagen in relation to the immature one when compared to W3S group, as the CMI of the former was greater than the one of the latter. This finding suggests that the administration of omega-3 in the week before the surgical intervention stimulates the production of mature collagen in malnourished animals. The CMI was also significantly higher in the M3S group compared with the MOS one. This finding supports the idea that preoperative administration of omega-3 can reverse the deleterious effects of malnutrition in the production of mature collagen in the healing anastomotic environment.

The migration and proliferation of fibroblasts and myofibroblasts in the healing environment, and consequently the production of collagen, is mediated by the action of inflammatory prostanoids (prostaglandins and leukotrienes) produced by inflammatory cells. Therefore, the higher CMI in the M3S group in relation to the MOS is possibly correlated with the higher level of cellular activity observed in the M3S group compared with the MOS group.

Another finding of this study that favors the concept of immunomodulation produced by omega-3 was the observation made in the number of blood vessels (neoangiogenesis) in the anastomotic healing environment. In immunohistochemistry, CD31 is mainly used to demonstrate the presence of endothelial cells in histologic tissue sections. This allows evaluating the degree of tissue angiogenesis ${ }^{23}$. We observed a decrease in the number of blood vessels in the MOP group in relation to the MOS group, suggesting that the administration of paclitaxel, which is a drug with antiangiogenic action ${ }^{24}$, is the causative factor of such reduction, agreeing with another study ${ }^{8}$ that showed significant reduction in neovascularization of colonic anastomoses of rats receiving paclitaxel. Supplementation with omega-3 in the M3P group was associated with recovery of the number of vessels, since this number was higher in this group compared with the MOP group. This finding suggests that the inhibition that paclitaxel causes on neoangiogenesis of the colonic anastomosis healing process can be reversed with the addition of omega-3 preoperatively. It is speculated that the eicosanoids produced by the metabolism of omega- 3 fatty acids, such as prostaglandin $E_{3}$ and leukotriene $B_{5}$, stimulate the migration and proliferation of endothelial cells precursors in the anastomotic environment.

Myofibroblasts are (predominantly) type I collagen-producing cells, and its quantification can also be used as a healing evaluation method ${ }^{13}$. Fibroblasts start to appear in the wound around the third day after surgery, proliferate in response to growth factors and begin to 
produce collagen ${ }^{25}$. We observed a significant reduction in the average number of myofibroblasts in the M3S group compared with the W3S one. This finding suggests that malnutrition is a deleterious effect to the myofibroblasts production. Trubian also found a significant reduction in the number of myofibroblasts in colonic anastomosis in malnourished rats ${ }^{13}$.

Proliferating cells are the very hallmark of anastomotic healing. The Ki-67 antigen is present on all active phases of the cell cycle (G1, S, G2 and mitosis), but is absent on resting cells $(\mathrm{GO})^{26}$. In this study, there was no difference between groups in the number of proliferating cells when assessed by Ki67. Given the previously reported findings and hypotheses developed, one would expect to find more proliferating cells in the groups receiving omega3 fatty acids, particularly in subgroups that did not receive chemotherapy, when compared with groups receiving olive oil, but we did not. We could not establish objective reasons for this. One suggested possibility is that proliferating cell types are different between the groups olive oil and omega3 fatty acids. In the latter, with healing mediated by eicosanoids of lower inflammatory potential (prostaglandin $\mathrm{E}_{3}$ and leukotriene $\mathrm{B}_{5}$ ) derived from the metabolism of omega-3 fatty acids, cell types would be composed of myofibroblasts, fibroblasts, endothelial cells and their precursors; in the former group (olive oil), with healing mediated by prostanoid of more inflammatory potential, other cell types would prevail, like polymorphonuclear and mononuclear ones.
In agreement with the literature, the data presented here suggest that the use of omega- 3 was associated with modulation of the inflammatory process, with stimuli to collagen production and to its quality in the anastomotic environment ${ }^{19}$. As already mentioned, the amount of mature collagen in relation to the immature, as measured by the CMI, was significantly higher in the M3S group compared with the MOS. Also in the M3S group, cellular activity represented by the inflammatory infiltrate in the anastomosis was higher than in the M3S group. These two concomitantly assessed findings support the idea that preoperative omega-3 administration in malnourished animals contributes positively to the healing process modulation of colonic anastomoses in rats, corroborating data from another work ${ }^{20}$, which pointed to the beneficial action of fatty acids.

The supplementation of omega-3 was also an important energy intake nutritional factor, as it attenuated weight loss in the M3S group compared with the MOS. This supplementation also played an important role in the recovery of the deleterious effects of paclitaxel on neoangiogenesis, since the number of blood vessels in the M3P group was higher than in the MOP one.

The exact mechanisms by which omega-3 may have acted to produce this study's findings still need to be clarified. Omega-3 fatty acids have immunomodulatory activities, still under study, on the production of cytokines, activation of T lymphocytes and angiogenesis ${ }^{27}$, which, when understood, can contribute to a better data comprehension.

\title{
R E S U M O
}

\begin{abstract}
Objetivo: avaliar o efeito da suplementação pré-operatória dos ácidos graxos ômega-3 sobre a cicatrização das anastomoses colônicas em ratos desnutridos que receberam paclitaxel. Métodos: foram estudados 160 ratos Wistar, distribuídos em dois grupos: um submetido à desnutrição pelo pair feeding (D) durante quatro semanas, e outro que recebeu ração ad libitum (N). Na quarta semana, os grupos foram subdivididos em dois subgrupos que receberam, por gavagem, ácido graxo ômega-3 ou azeite de oliva. Os animais foram submetidos à transecção colônica e anastomose término-terminal. Após a operação, foram distribuídos em dois subgrupos que receberam soluções isovolumétricas de salina ou paclitaxel, intraperitonial. Resultados: A mortalidade foi 26,8\%, maior no grupo de animais que recebeu paclitaxel $(p=0,003)$. A força de ruptura completa foi maior no grupo nutrido-azeitepaclitaxel (NAP) em relação ao grupo desnutrido-azeite-paclitaxel (DAP). O índice de maturação de colágeno foi maior no grupo nutrido-azeite-salina (NAS) em relação ao grupo desnutrido-azeite-salina (DAS), menor no grupo desnutrido-azeite-salina (DAS) em relação ao grupo desnutrido-ômega3-salina (DOS) e menor no grupo nutrido-ômega3-salina (NOS) em relação ao desnutridoômega3-salina (DOS). A contagem do número de vasos sanguíneos foi maior no grupo desnutrido-azeite-salina (DAS) em relação ao grupo desnutrido-azeite-paclitaxel (DAP) e menor no grupo desnutrido-azeite-salina (DAS) em relação ao grupo desnutrido-ômega3paclitaxel (DOP). Conclusão: a suplementação com ácidos graxos ômega-3 associou-se ao aumento significativo na produção de colágeno maduro nos animais desnutridos, à reversão do efeito deletério causado pela desnutrição em associação ao uso do paclitaxel, sobre a força de ruptura, e ao estímulo da neoangiogênese no grupo que recebeu paclitaxel.
\end{abstract}

Descritores: Anastomose Cirúrgica. Desnutrição. Acido Graxo Ômega-3. Paclitaxel.

\section{REFERENCES}

1. Siegel R, Ward E, Brawley O, Jemal A. Cancer statistics, 2011: the impact of eliminating socioeconomic and racial disparities on premature cancer deaths. CA Cancer J Clin. 2011;61(4):212-36.
2. du Bois A, Quinn M, Thigpen T, Vermorken J, Avall-Lundqvist E, Bookman M, et al. 2004 consensus statements on the management of ovarian cancer: final document of the 3rd International Gynecologic Cancer Intergroup Ovarian Cancer Consensus Conference (GCIG OCCC 2004). Ann Oncol. 2005;16 Suppl 8:viii7-viii12. 
3. Trimbos JB, Parmar M, Vergote I, Guthrie D, Bolis G, Colombo N et al. International Collaborative Ovarian Neoplasm trial 1 and Adjuvant ChemoTherapy In Ovarian Neoplasm trial: two parallel randomized phase III trials of adjuvant chemotherapy in patients with early-stage ovarian carcinoma. J Natl Cancer Inst 2003;95(2):105-12.

4. Campos ACL. Tratado de nutrição e metabolismo em Cirurgia. Rio de Janeiro: Rubrio; 2013.

5. Braga M, Gianotti L, Nespoli L, Radaelli G, Di Carlo V. Nutritional approach in malnourished surgical patients. A prospective randomized study. Arch Surg. 2002;137(2):174-80.

6. Kavalukas SL, Barbul A. Nutrition and wound healing: an update Plast Reconstr Surg. 2011;127 Suppl 1:38S-43S.

7. Balogun N, Forbes A, Windswendter M, Lanceley A. Noninvasive nutritional management of ovarian cancer patients: beyond intestinal obstruction. Int J Gynecol Cancer. 2012;22(6):1089-95

8. Yüceyar S, Ertürk S, Temiz M, Do $\square$ usoy G, Gümüstas K, Ozgüro $\square$ lu $\mathrm{M}$, et al. Role of the antiangiogenetic drug paclitaxel on healing of intestinal anastomosis: an experimental study. Tech Coloproctol. 2005:9(3):201-5

9. Bozkurtoglu H, Bozkurt S, Celik F, Kaya MA, Zemheri E. Effect of the intraperitoneal paclitaxel on the healing of colonic anastomosis. Int Surg. 2005;90(1):12-7.

10. Calder PC. Immunomodulation by omega-3 fatty acids Prostaglandins Leukot Essent Fatty Acids. 2007;77(5-6):327-35.

11. Waitzberg DL, Torrinhas RS, Jacintho TM. New parenteral lipid emulsions for clinical use. JPEN J Parenter Enteral Nutr. 2006;30(4):351-67.

12. Knightly JJ, Agostino D, Cliffton EE. The effect of fibrinolysin and heparin on the formation of peritoneal adhesions. Surgery. 1962; 52:250-8.

13. Trubian PS. Nutrição perioperatória e cicatrização de anastomoses em ratos desnutridos e toxêmicos: tensiometria, densitometria do colágeno e quantificação de angiogênese e miofibroblasto [tese]. Curitiba: Universidade Federal do Paraná, Ciências da Saúde; 2008.

14. von Gruenigen VE, Huang HQ, Gil KM, Frasure HE, Armstrong DK. Wenzel LB. The association between quality of life domains and overall survival in ovarian cancer patients during adjuvant chemotherapy: a Gynecologic Oncology Group Study. Gynecol Oncol. 2012;124(3):379-82

15. Vizzotto Júnior $A O$, Noronha L, Scheffel DLH, Campos ACL. Influência da cisplatina administrada no pré e no pós-operatório sobre cicartrização de anastomoses colônicas em ratos. J Bras Patol Med Lab. 2003;39(2):143-9.

16. Gonçalves CG, Groth AK, Ferreira M, Matias JE, Coelho JC, Campos AC. Influence of preoperative feeding on the healing of colonic anastomosis in malnourished rats. JPEN J Parenter Enteral Nutr. 2009;33(1):83-9.
17. Farreras N, Artigas V, Cardona D, Rius X, Trias M, Gonzáles JA Effect of early postoperative enteral immunonutrition on wound healing in patients undergoing surgery for gastric cancer. Clin Nutr. 2005;24(1):55-65.

18. Aoyama T, Hayashi T, Fujikawa H, Ogata T, Cho H, Wada H, et al. Effect of enteral nutrition enriched with eicosapentaenoic acid on body weight loss and compliance with S-1 adjuvant chemotherapy after gastric cancer surgery. Gan To Kagaku Ryoho. 2013:40(12):2289-91.

19. Doillon CJ, Dunn MG, Berg RA, Silver FH. Collagen deposition during wound repair. Scan Electron Microsc. 1985;(Pt 2):897-903.

20. Ekçi B, Karabicak I, Atukeren P, Altinlio E, Tomaoglu K, Tasci I. The effect of omega-3 fatty acid and ascorbic acid on healing of ischemic colon anastomoses. Ann Ital Chirur. 2011;82(6):475-9.

21. McDaniel JC, Belury M, Ahijevych K, Blakely W. omega-3 fatty acids effects on wound healing. Wound Repair Regen. 2008;16(3):337-45.

22. Cockbain AJ, Toogood GJ, Hull MA. Omega-3 polyunsaturated fatty acids for the treatment and prevention of colorectal cancer. Gut. 2012:61(1):135-49.

23. Jackson DE. The unfolding tale of PECAM-1. FEBS Lett. 2003;540(13):7-14.

24. Klein LE, Freeze BS, Smith AB 3rd, Horwitz SB. The microtubule stabilizing agent discodermolide is a potent inducer of accelerated cell senescence. Cell Cycle. 2005;4(3):501-7.

25. Kiyama T, Witte MB, Thornton FJ, Barbul A. The route of nutrition support affects the early phase of wound healing. JPEN J Parenter Enteral Nutr. 1998;22(5):276-9

26. Bullwinkel J, Baron-Lühr B, Lüdemann A, Wohlenberg C, Gerdes J, Scholzen T. Ki-67 protein is associated with ribosomal RNA transcription in quiescent and proliferating cells. J Cell Physiol. 2006;206(3):624-35.

27. Segura JG. Extração e caracterização de óleos de resíduos de peixe de água doce [dissertação]. Pirassununga/SP: Universidade de São Paulo, Faculdade de Zootecnia e Engenharia de Alimentos; 2012

Received on 10/07/2014

Accepted for publication 15/08/2014

Conflict of interest: none.

Source of funding: none.

Address for correspondence:

Alvo Orlando Vizzotto Junior

E-mail: alvovizz@hotmail.com 